НАУКОВИЙ ВІСНИК

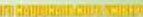

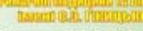

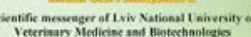

7

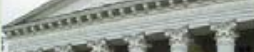

IIIM

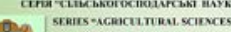

Toм 21 Nes 90

2019
Науковий вісник Дьвівського національного університету ветеринарної медицини та біотехнологій імені С.3. Гжицького. Серія: Сільськогосподарські науки

Scientific Messenger of Lviv National University of Veterinary Medicine and Biotechnologies.

Series: Agricultural sciences

ISSN 2519-2698 print

https://nvlvet.com.ua/index.php/agriculture

doi: $10.32718 /$ nvlvet-a9020

\title{
Quality control system for meat processing enterprises in Ukraine: problems and ways of their solution
}

\author{
I.C. Stetsiv ${ }^{1}$, I.I. Stetsiv ${ }^{2}$ \\ ${ }^{I} N U$ "Lviv Polytechnic", Lviv, Ukraine \\ ${ }^{2}$ Lviv State University of Life Safety, Lviv, Ukraine
}

Article info

Received 19.02.2019

Received in revised form 19.03.2019

Accepted 20.03.2019

National University

"Lviv Polytechnic",

Stepan Bandera Str., 12 Lviv 79013, Ukraine.

Tel.: +38-099-188-77-21

E-mail: irina.s.stetsiv@lpnu.ua

Lviv State University of Life Safety, Kleparivska Str., 35, Lviv, 79007, Ukraine.
Stetsiv, I.C., \& Stetsiv, I.I. (2019). Quality control system for meat processing enterprises in Ukraine: problems and ways of their solution. Scientific Messenger of Lviv National University of Veterinary Medicine and Biotechnologies. Series: Agricultural sciences, 21(90), 113-120. doi: 10.32718/nvlvet-a9020

We have researched the scientists' opinions on the classification of product quality control and, based on the research conducted, organized a classification using a scientifically based approach. In general, the attention of scientists is paid to factors affecting the quality of products, while issues of the quality control system and factors of influence on it are insufficiently investigated. We have identified and grouped the factors influencing the quality control system of domestic meat processing enterprises by organizational, technical and subjective features. We conducted a survey of leading specialists of the most successful representatives of the meat processing industry today in order to identify the rating of negative factors. The most important factors of influence are the serviceability of equipment, devices, working tools and measuring instruments, through which the level of its quality is measured. We investigated the typical scheme of the production process, indicating the quality control points of domestic meat processing enterprises. We have found a lack of control of the value of meat raw materials at the entrance, which does not allow calculating with suppliers of raw materials, depending on the categories to which the pork actually belongs. We recommend that quality control be performed at the slaughter section between the 4th and 5th stages of the technological stage, namely after the sting of a pig with the use of special devices that are currently absent in domestic meat processing plants. The proposed measures to improve the quality control system will provide an opportunity for a comprehensive assessment of its quality and contribute to a reduction in the cost of production, resulting in increased profitability of enterprises, which suggests the feasibility of their use for meat processing enterprises in Ukraine. The three-dimensional matrix model of quality control of products of meat processing enterprises has been developed. The advantage of this model lies in the coherence of all parameters, as well as in establishing interrelationships and interdependencies between them. It is proved that the application of the proposed multivariate matrix model of product quality control in the indicated parameters enables to evaluate the quality of the meat-processing enterprise's products, taking into account all parameters of control, namely levels of control, types of control, stages of the control process and can be used for any subject of economic activity taking into account industry specifics and specific management objectives.

Key words: control parameters, control points, three-dimensional matrix model of control.

\section{Система контролю якості продукції м'ясопереробних підприсмств України: проблеми та шляхи їх вирішення}

\author{
I.C. Стеців ${ }^{1}$, I.I. Стеців ${ }^{2}$ \\ ${ }^{1}$ НУ “Львівська політехніка”, м. Львів, Україна \\ ${ }^{2}$ Львівський державний університет безпеки життєдіяльності, м. Львів, Украӥна
}

Досліджено підходи вчених до класифікащії видів контролю якості продукиї суб 'єктів економіки та, на основі проведеного дослідження, впорядковано класифікацію із застосуванням науково обтрунтованого підходу. Виявлено, щчо увага вчених приділяється чинникам, щуо впливають на якість продукиї, тоді як питання системи контролю якості та чинників впливу на неї досліджені в 
недостатній мірі. Визначено та згруповано чинники впливу на систему контролю якості продукиії вітчизняних м'ясопереробних підприємств за організачійними, технічними та суб'єктивними ознаками. Проведено опитування провідних спеціалістів найуспішніших на сьогодні представників м'ясопереробної галузі з метою виявлення рейтингу негативних чинників. Встановлено, шео найвагомішими з чинників впливу є справність устаткування, пристроїв, робочого інструменту і контрольно-вимірювальних приладів, за допомогою яких вимірюється рівень ї̈ якості. Досліджено типову схему виробничого процесу із зазначенням точок контролю якості продукиії вітчизняних м'ясопереробних підприємств. Виявлено відсутність контролю иінності м'ясної сировини на вході, що не дозволяє здійснювати розрахунок з постачальниками сировини залежно від категорій до якої фактично належить свинина. Рекомендовано здійснювати контроль якості на забійній дільниці між 4 та 5 етапами технологічного етапу, а саме після оглушування свині із використанням спечіальних пристроїв, які на сьогодні відсутні на вітчизняних м'ясопереробних підприємствах. Доведено, що запропоновані заходи по удосконаленню системи контролювання якості продукції забезпечать можливість всебічної оцінки ї̈ якості та сприятимуть зниженню собівартості продукиії, внаслідок чого прибутковість підприємств зростатиме, щчо свідчить про доцільність їх застосування для м'ясопереробних підприємств Украӥни. Розроблено тривимірну матричну модель контролю якості продукиії м'ясопереробних підприємств. Визначено перевагу иієї моделі, яка полягає в узгодженості усіх параметрів а також у встановленні взаємозв'язків та взаємозалежностей між ними. Доведено, щьо застосування запропонованої багатовимірної матричної моделі контролю якості продукиії у зазначених параметрах дає змогу оцінити якість продукції м'ясопереробного підприємства із врахуванням усіх параметрів контролю, а саме рівнів контролю, видів контролю, етапів контрольного процесу та може використовуватись для будь якого суб 'єкта господарювання з урахуванням галузевих особливостей та конкретних ијілей управління.

Ключові слова: параметри контролю, точки контролю, тривимірна матрична модель контролю.

\section{Вступ}

В умовах сучасного стану економіки якість продукції $€$ зведеним поняттям, яке повинне враховувати інтереси всіх учасників національного господарювання, в тому числі і м'ясопереробних підприємств, для яких якість продукції $є$ гарантією та вирішальним фактором забезпечення їх конкурентоспроможності, стійкості, авторитету та успішності функціонування. 3 іншого боку для споживачів підвищення якості є умовою задоволення їх потреб і захисту прав; для органів влади забезпечення якості життя громадян є одним із пріоритетних державних завдань. Оскільки харчова галузь будь якої держави являється однією із найважливіших, бо не тільки виступає однією із основних ланок економіки, але й має безпосередній вплив на здоров'я та якість життя населення країни. Саме тому питання контролю якості продукції підприємств харчової галузі та тваринництва зокрема є чи найактуальнішими на будь якому етапі розвитку суспільства.

Проблемам управління якістю та підвищення іiі рівня на м'ясопереробних підприємствах присвячені праці багатьох вітчизняних та зарубіжних фахівців. Зокрема, серед них можна виокремити таких: Клименко Л.П., Пізінцалі Л.В., Александровської Н.І., Свдокимова В.Д., Логоша Р.В., а також Bechtel P., Bland J., Woods K., Lea J., Brashear S., Djenane D., Roncalés P., Giovannucci D., Satin M. та інші. Водночас не розв'язаними залишаються питання побудови систем контролю якості продукцї м'ясопереробних підприємств та забезпечення їх ефективного функціонування.

Отже, метою даної статті є дослідження теоретичних і практичних аспектів побудови системи контролю якості та вироблення практичних рекомендацій щодо забезпечення іiі ефективного функціонування на м'ясопереробних підприємствах. Досягнення поставленої мети зумовило вирішення наступних завдань: проаналізувати стан та проблеми контролю якості продукції на м'ясопереробних підприємствах України; визначити чинники впливу на систему контролю якості продукції вітчизняних м'ясопереробних підприємств; дослідити систему контролю якості продукції м'ясопереробних підприємств; розробити заходи $з$ удосконалення системи контролю якості продукції м'ясопереробних підприємств.

\section{Матеріал і методи досліджень}

Дослідження базувалося на матеріалах публікацій 3 проблем організації ефективної системи контролю якості продукції м'ясопереробних підприємств України, фактологічному, статистичному матеріалі, даних досліджень українських і зарубіжних науковців. У процесі дослідження було використано методи порівняльного аналізу, синтезу, узагальнення, абстрактнологічний, системний підхід до дослідження економічних процесів.

\section{Результати та їх обговорення}

Важливу роль у безперебійному забезпеченні населення продуктами харчування відіграють підприємства м'ясопереробного спрямування. Їх діяльність на сьогодні характеризується зростанням основних економічних показників, які вказують на розширення даного сектору економіки. Натомість сільгоспвиробники сировини потрапили у негативне становище будучи залежними від м'ясопереробних підприємств, які обрали тактику зниження витрат за рахунок зниження закупівельної ціни на сировину. Не відповідність цін на м'ясну продукцію призводить до збитковості діяльність сільгоспвиробників, оскільки вони намагаються взяти ринок не якістю, а кількістю. Відповідно якість падає і назріває нова хвиля негативних наслідків, але вже для м'ясопереробних підприємств та споживачів продукції. Саме тому контроль якості продукції відіграє важливу роль не лише для споживачів м'ясної продукції, але i для самих м'ясопереробних підприємств.

Для ефективного вивчення даної проблеми та пошуку шляхів іiї вирішення необхідним є дослідження основних понять та визначень, що стосуються контролю якості м'ясної продукції. Огляд літературних джерел вказує на неоднозначність підходів вчених до класифікації видів контролю якості продукції (Klymenko et al., 2011; Popova \& Mysiura, 2012; Vershyhora, 2015). 
Для покращення наочного сприйняття нами згруповано види контрою якості продукції у розрізі основних ознак, що представлено на рисунку 1. До основних ознак на наш погляд слід віднести етапи процесу виробництва, повноту охоплення продукції контролем, вплив на можливість подальшого використання виборів, охоплення фізичних та хімічних властивос- тей м'ясної продукції. Такий вибір є не випадковий оскільки побудова ефективної системи контролю якості продукції, яка базується на охопленні наведених видів контролю у розрізі вказаних ознак дає можливість приймати обгрунтовані управлінські рішення у процесі функціонування м'ясопереробного підприємства.

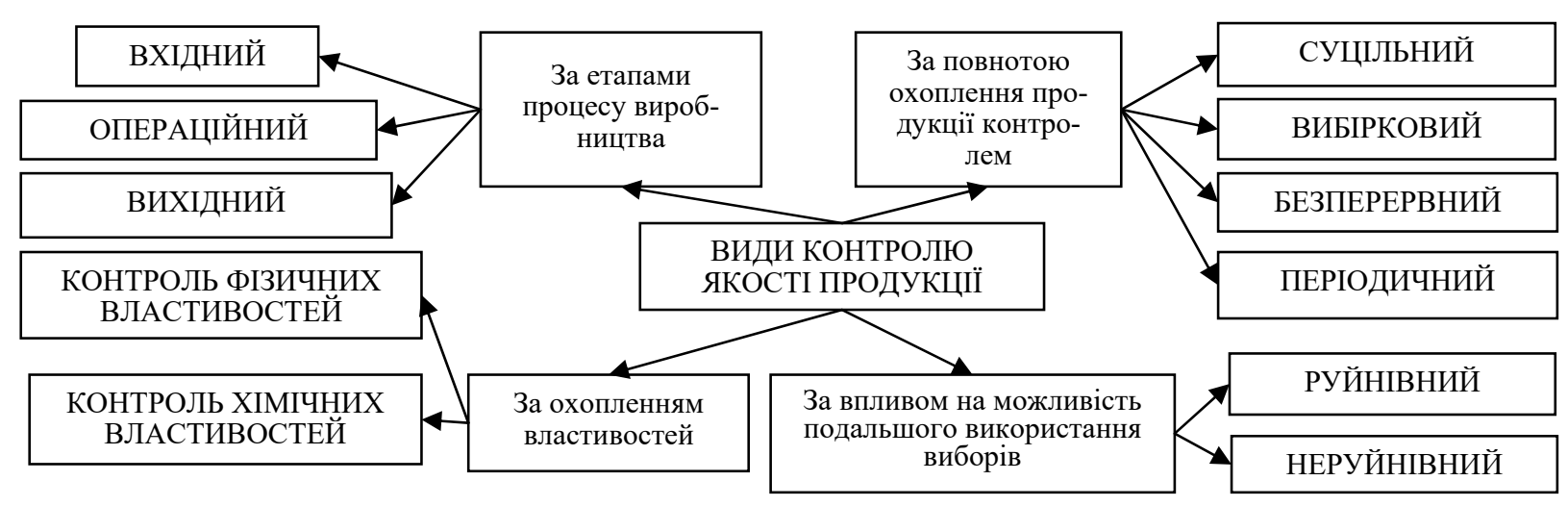

Рис. 1. Види контролю якості продукції м’ясопереробних підприємств складено автором на основі (Klymenko et al., 2011; Popova \& Mysiura, 2012; Vershyhora, 2015)

На наш погляд особливої уваги потребує дослідження стану контролю якості продукції м'ясопереробних підприємств у розрізі охоплення контролем ії фізичних та хімічних властивостей.

Контроль хімічних властивостей відбувається відповідно 3 сучасними міжнародними вимогами до якості і безпеки харчових продуктів, у зв'язку з необхідністю виробництва та реалізації доброякісної у ветеринарно-санітарному відношенні продукції тваринного походження. Зокрема Державним департаментом ветеринарної медицини, затверджений обов'язковий мінімум досліджень сировини, продукції тваринного та рослинного походження, які слід проводити в лабораторіях ветмедицини. Даний контроль відіграє важливу роль для споживача так як виступає гарантом безпеки вживання м'ясної продукції.

Щодо контролю фізичних властивостей м'ясної продукції, то на наш погляд вона повинна здійснюватись як на виході виробничої системи м'ясопереробного підприємства так і на вході, оскільки обгрунтоване оцінювання фізичних властивостей сировини на вході $є$ запорукою високої рентабельнос- ті реалізованої продукції на виході.

Система контролю якості продукції вітчизняних м'ясопереробних підприємств на сьогодні характеризується значними негативними рисами, що перешкоджають іï безперебійному функціонуванню. Для виокремлення основних чинників впливу на систему контролю якості продукції вітчизняних м'ясопереробних підприємств нами проведене дослідження доступних літературних джерел. Загалом увага вчених приділяється чинникам, що впливають на якість продукції, тоді як питання системи контролю якості досліджені в недостатній мірі, зокрема дослідження потребують чинники, що впливають на систему контролю якості м'ясопереробних підприємств (Giovannucci \& Satin, 2007; Li et al., 2017; Djenane \& Roncalés, 2018; Leal-Ramos et al., 2018; Bechtel et al., 2018).

Огляд літературних джерел та дослідження практичної діяльності м'ясопереробних підприємств дає підстави згрупувати чинники впливу на систему контролю якості продукції у розрізі певних класифікаційних ознак (табл. 2).

\section{Таблиця 2}

Чинники впливу на систему контролю якості продукції

\begin{tabular}{cl}
\hline Класифікаційні ознаки & \multicolumn{1}{c}{ Чинники впливу на систему контролю } \\
\hline Організаційні & - технічна документація, за якою здійснюється перевірка якості продукції \\
Технічні & - справність устаткування, пристроїв, робочого інструменту і контрольно-вимірювальних \\
& приладів, за допомогою яких вимірюється рівень ії якості \\
Суб’єктивні & - відповідність рівня кваліфікації персоналу вимогам, що забезпечують якісне виконання \\
& контрольної роботи
\end{tabular}

Для покращення системи контролю якості значне практичне значення має вивчення негативних чинників впливу на систему контролю якості. Наявність вищенаведених чинників може мати як негативний так і позитивний характер. Для виявлення рейтингу негативних чинників необхідним є дослідження думки експертів задіяних у практичній діяльності підприємств м'ясопереробної галузі. 
Нами проведено опитування провідних спеціалістів найуспішніших на сьогодні представників м'ясопереробної галузі, що можуть виступати експертами у питаннях контролю якості продукції м'ясопереробних підприємств.

Загалом експертне оцінювання мало вигляд анкети де кожен експерт мав можливість оцінити на свій розсуд чинники впливу на систему контролю за 3-ох бальною шкалою, де в 1 бал оцінюється найменший можливий негативний вплив чинника на систему контролю якості продукції м'ясопереробного підприємства, а в 3 бали - найбільший. Результати проведеного опитування згруповані у таблиці 3.

\section{Таблиця 3}

Експертна оцінка вагомості чинників впливу на систему контролю якості продукції м'ясопереробних підприємств

\begin{tabular}{|c|c|c|c|}
\hline \multirow{2}{*}{ Експерти підприємства } & \multicolumn{3}{|c|}{ Чинники впливу на систему контролю } \\
\hline & Суб’єктивні & Технічні & Організаційні \\
\hline ТзОВ “Ходорівський м’ясокомбінат” & 3 & 1 & 2 \\
\hline ПП “Сегрос" & 1 & 3 & 2 \\
\hline ТОВ МК “РІАЛ" & 1 & 2 & 3 \\
\hline ТОВ “Виробнича компанія “АТЛАНТ” & 3 & 2 & 1 \\
\hline ТОВ “Житомирський м’ясокомбінат” & 2 & 3 & 1 \\
\hline ТОВ “АНТОНІВСЬКИЙ М’ЯСОКОМБІНАТ” & 2 & 3 & 1 \\
\hline ПКВКП “Еліта" & 2 & 1 & 3 \\
\hline ТОВ “Барвінок Інвест” & 2 & 3 & 1 \\
\hline ТОВ Харківський м'ясокомбінат & 3 & 2 & 1 \\
\hline ПрАТ “Кременчукм’ясо” & 2 & 1 & 3 \\
\hline ТзОВ “Лембергміт” & 2 & 3 & 1 \\
\hline ТОВ “Алан” & 3 & 3 & 2 \\
\hline ТОВ “Новокаховський м’ясокомбінат “Мрія” & 2 & 3 & 1 \\
\hline ДП МК “Росана” & 2 & 3 & 1 \\
\hline ТОВ "Юрмія" & 2 & 1 & 3 \\
\hline ТОВ “М’ясокомбінат “Ювілейний” & 2 & 1 & 3 \\
\hline ТОВ “Миргородський м'ясокомбінат” & 3 & 2 & 1 \\
\hline ТОВ “Дружба & 2 & 3 & 1 \\
\hline ТОВ “Глобинський м’ясокомбінат” & 2 & 3 & 1 \\
\hline ТОВ М'ясна фабрика “Фаворит плюс” & 1 & 3 & 2 \\
\hline ТДВ “Мясокомбінат “Ятрань” & 2 & 3 & 1 \\
\hline Разом балів & 44 & 49 & 35 \\
\hline
\end{tabular}

* Складено автором на основі проведеного дослідження

На основі проведеного дослідження нами виведено рейтинг чинників впливу на систему контролю якості продукції м'ясопереробних підприємств, що відображено у таблиці 4.

За результатами дослідження можна зробити висновок, що на думку експертів найвагомішим чинником впливу на систему контролю якості продукції м'ясопереробних підприємств є справність устаткування, пристроїв, робочого інструменту і контрольновимірювальних приладів, за допомогою яких вимірюється рівень ऑї якості, оскільки відсутність даного обладнання на сьогодні унеможливлює здійснення контролю якості на належному рівні.

\section{Таблиця 4}

Рейтинг чинників впливу на систему контролю

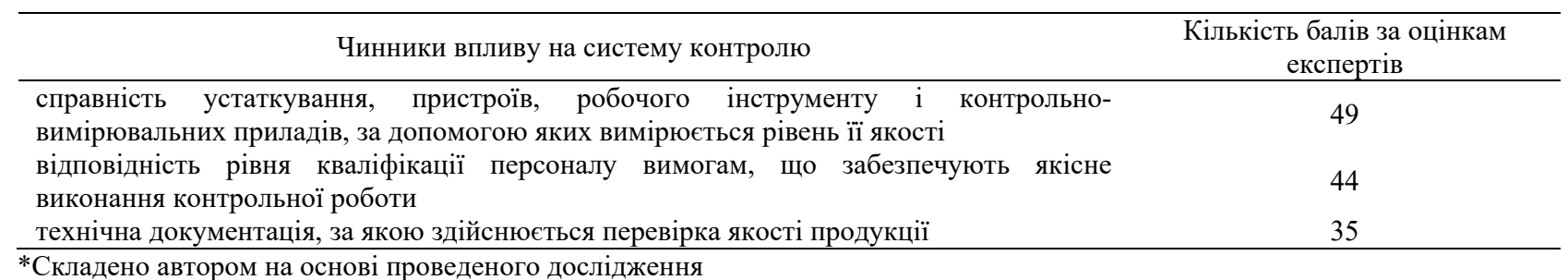

Формування дієвої системи контролю якості продукції м'ясопереробних підприємств є складним процесом, що потребує ретельного вивчення діяльності їх та застосування певних методичних підходів і хоча необхідність іiі застосування $є$ надзвичайно необхідною, на сьогодні не існує єдиного методичного підходу до ii реалізації у практичній діяльності підпри- ємств.

Поряд 3 тим Україна намагається наблизитись до світових стандартів, зокрема у рамках співпраці Асоціації “Свинарі України” та Міністерства сільського господарства США в Україну завітали експертидорадники, професори Purdue University, для здійснення аудиту біобезпеки свиноферм та 
м'ясопереробних підприємств, а також з перевіркою вітчизняних господарств за американською системою контролю якості свинини PQA Plus (освітня та сертифікаційна програма контролю якості свинини. Вона охоплює спектр питань, пов'язаних з безпекою харчових продуктів, благополуччям тварин, захистом навколишнього середовища та безпекою працівників).

Проте на сьогодні м'ясопереробні підприємства стикаються із проблемами оцінки якості продукції при купівлі сировини у вигляду живої ваги, оскільки заявлені постачальниками якості тварин переважно не відповідають належному рівню, внаслідок чого м'ясопереробні підприємства втрачають значну частину сировини ще на первинному рівні виробництва. Враховуючи особливості технологічного процесу м'ясопереробного підприємства варто зауважити, що норми втрат сировини (виходу м'ясної продукції) можуть значно коливатись у залежності від якості сировини, а саме категорії до якої вона належить.

На сьогодні приділяється не достатня увага контролю вхідної сировини за фізичними властивостями, що негативно впливає на рентабельність продукції м'ясопереробного підприємства, оскільки вказана сировина становить основну частку собівартості продукції. Проведене дослідження, висвітлене у таблиці 4 дає підстави вважати, що основною причиною такого стану речей може бути відсутність відповідного обладнання, що дозволяє 3 великою точністю визначити до якої категорії відноситься отримана від постачальників сировина та здійснювати оплату безпосередньо після забою тварин згідно встановленої якості м'яса, а не за середніми ринковими цінами, що значно підвищить показники діяльності підприємств та буде стимулювати постачальників свинини до іï покращення якості.

При цьому науковці виділяють 5 основних факторів, за якими м'ясна продукція повинно відповідати споживчим вимогам: органолептична привабливість (соковитість, ніжність); значення для здоров'я (вміст пісного високоякісного білка і поживних речовин); екологічний аспект; співвідношення ціни і якості (Pethick et al., 2010).

Окремі вчені пропонують оцінювати м'ясо за наступними властивостями: колір філе; колір поверхні різання; колір м'ясного соку; обсяг м'ясного соку; газоутворення; текстури; загальний вигляд (Mack et al., 2014).

Інші вказують на необхідність моніторингу температури продукту по всьому холодному ланцюгу i обмін даними температури, для отримання повної інформації про температуру для прогнозування залишкового терміну придатності або стану якості (Raab et al., 2011; Bruckner et al., 2012). При цьому вчені вказують на необхідність застосування спеціальних приладів бездротового зв'язку (Jedermann et al., 2014), а також доводять значний вплив упаковки на якість продукції (Zhang et al., 2016).

У ході дослідження системи контролю якості продукції вітчизняних м'ясопереробних підприємств нами розроблено типову схему виробничого процесу iз зазначенням точок контролю якості продукції.

Як демонструє рис. 2 типово на підприємствах існує 4 точки контролю якості продукції, зокрема такі як: ТК 1 - огляд та ВСЕ підщелепових лімфатичних вузлів та голови на наявність сибірки, огляд та ВСЕ голови на наявність паразитів; ТК 2 - огляд та ВСЕ внутрішніх органів та відбір ніжок діафрагми для трихінелоскопії; ТК 3 - огляд та ВСЕ півтуш на наявність паразитів, залишків спинного мозку, крововиливів, пухлин та інших патологічних змін; ТК 4 - фінальний огляд та ВСЕ півтуш на наявність паразитів залишків спинного мозку, крововиливів, пухлин та інших патологічних змін. Клеймування позначкою придатності.

В ході проведеного дослідження нами встановлено відсутність контролю цінності м'ясної сировини на вході, що не дозволяє здійснювати розрахунок з постачальниками сировини залежно від категорій до якої фактично належить свинина. На наш погляд така оцінка повинна здійснюватись на забійній дільниці між 4 та 5 етапами технологічного етапу, а саме після оглушування свині із використанням спеціальних пристроїв, які на сьогодні відсутні на вітчизняних м'ясопереробних підприємствах, що негативно відображається на функціонування системи контролю якості продукції.

На наш погляд, методика контролю якості продукції м'ясопереробного підприємства на сам перед повинна бути розроблена та впроваджена в межах підприємства та має будуватися у відповідності до описаних попередньо видів контролю, що враховуватимуть технологічний процес та властивості продукції, тобто давати відповіді на питання: “що контролювати?”, “коли контролювати?” та “ким контролювати?”. Загалом систему контролю якості продукції можна зобразити у вигляді тривимірної матриці (рис. 3).

Суть матричної моделі контролю якості продукції полягає у одночасній характеристиці контролю за трьома різними параметрами контролю. Для цього ми використали декартову ортогональну систему координат де осі $\mathrm{x}, \mathrm{y}, \mathrm{z}$ - відповідають параметрам контролю. Матриця набуває вигляду паралелепіпеду поділену на і-ту кількість кубів (елементів матриці). Положення кубу задається трьома елементами за перпендикулярною проекцією куба на ортогональні осі х, y, та z, в проміжки певних трьох параметрів контролю, за якою куб відповідатиме характеристикам одночасно виду контролю, етапам контролю та рівню контролю, що задано змінною з трьома індексами. Матриця виступає у ролі тривимірної таблиці в кожний куб якої вводиться величина показника, що відповідає рівню якості продукції, оціненої від 0 до 1 (де 0 - повна невідповідність визначеним вимогам, а 1 - повна відповідність), скорегована на величину V, що характеризує вагомість даного показника для підприємства. Суми стовбців вказують на загальну величину показника за вказаним елементом. 


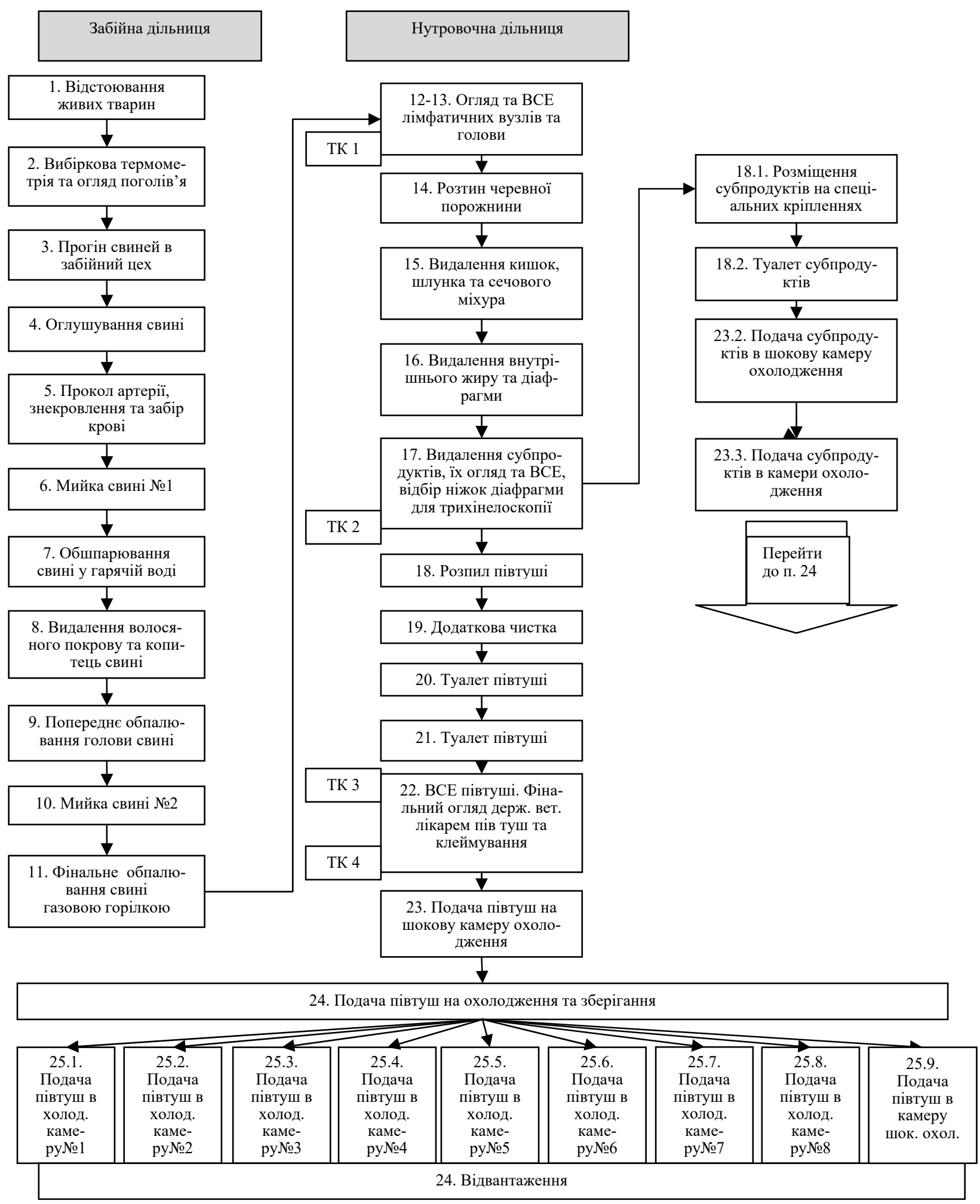

Рис. 2. Схема виробничого процесу м'ясопереробного підприємства (Складено автором на основі проведеного дослідження) 


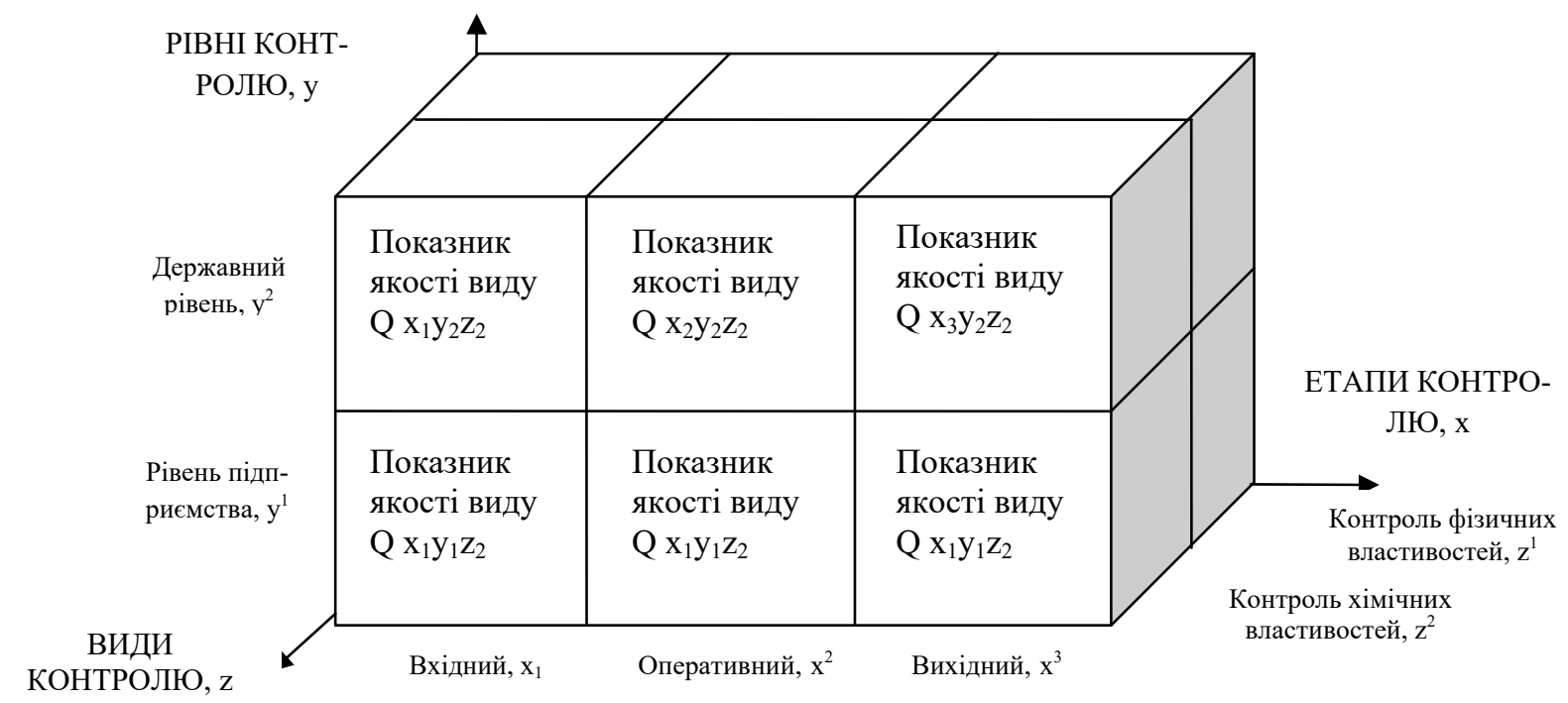

Рис. 3. Тривимірна матрична модель контролю якості продукції м’ясопереробних підприємств.

[*Складено автором на основі проведеного дослідження]

Загальна сума за усіма елементами складає інтегрований показник оцінки якості продукції ( integrated quality score ) розроблений нами з метою підвищення точності визначення якості продукції. Величина даного показника при абсолютній відповідності встановленим нормам якості дорівнює 1 , що визначається за наступною формулою (1):

$$
\sum_{E=1}^{n} Q_{\mathrm{x}_{n} \mathrm{y}_{n} z_{n}} * V=1
$$

де $\mathrm{E}$ - елемент матриці, $\mathrm{n}$ - кількість елементів матриці, $\mathrm{Q}_{\mathrm{x}, \mathrm{y}, \mathrm{z}}$ - показник якості виду х, y, z, V - коефіці$\epsilon$ вт вагомості, 1 - бажане значення.

Вищенаведена тривимірна матрична модель контролю якості продукції м'ясопереробного підприємства може застосовуватись для будь якого суб'єкта господарювання з урахуванням галузевих особливостей та конкретних цілей управління. Для перевірки контролю якості продукції доцільно формувати методологічну карту, що дозволить повністю охопити контролем об’єкт перевірки та приймати відповідні рішень за його результатами (Rudnytskyi et al., 2010).

На наш погляд для покращення показників прибутковості м'ясопереробних підприємств особливу увагу слід приділяти показнику $\mathrm{Q} \mathrm{x}_{1} \mathrm{y}_{1} \mathrm{z}_{1}$, оскільки проведене дослідження вказує на відсутність його контролю на м'ясопереробних підприємствах України (див. рис. 2). Як наслідок оплата постачальникам вихідної сировини здійснюється за середніми ринковими цінами, не залежно від категорій до якої фактично належить свинина. Це негативно впливає не лише на витрати м'ясопереробних підприємств, але і на виробників худоби, які втрачають стимул покращувати iіi якість. Вирішення даного питання повинно базуватися на придбанні високотехнологічного обладнання по вимірюванню якості сировини, відразу після забою, яке на сьогодні представлене різними виробниками. Зокрема на увагу заслуговує CGM від SYDEL, який зарекомендував себе у м'ясопереробній галузі Свросоюзу як найточніший прилад для тестування м'яса. Пристрій CGM відповідає вимогам ЄC, єдиний має поточні схвалення СС (у Франції та Бельгії). У Франції в даний час використовуються майже 180 пристроїв CGM, з якими випробовується 95\% всіх туш у цій країні. У Бельгії є 18 пристроїв, а в Польщі пристрої CGM були встановлені в більш ніж 100 компаніях.

\section{Висновки}

В результаті проведеного дослідження можемо зробити висновок, що запропоновані заходи по удосконаленню системи контролювання якості продукції забезпечать можливість всебічної оцінки іiі якості та сприятимуть зниженню собівартості продукції, внаслідок чого прибутковість підприємств зростатиме, що свідчить про доцільність їх застосування для м'ясопереробних підприємств України. Запропонована тривимірна матрична модель контролю якості продукції м'ясопереробного підприємства дає змогу оцінити якість продукції м'ясопереробного підприємства iз врахуванням усіх параметрів контролю, а саме рівнів контролю, видів контролю, етапів контрольного процесу та може застосовуватись для будь якого суб'єкта господарювання 3 урахуванням галузевих особливостей та конкретних цілей управління.

\section{References}

Bechtel, P., Bland, J., Woods, K., Lea, J., Brashear, S., Boue, S., Daigle, K., \& Bett-Garber, K. (2018). Effect of Par Frying on Composition and Texture of Breaded and Battered Catfish. Foods, 7(4), 46. doi: 10.3390 foods 7040046.

Bruckner, S., Albrecht, A., Petersen, B., \& Kreyenschmidt, J. (2012). Influence of cold chain interruptions on the shelf life of fresh pork and poultry. Int. J. Food Sci. Tech., 47(8), 1639-1646. doi: 10.1111/j.1365-2621.2012.03014.x.

Djenane, D., \& Roncalés, P. (2018). Carbon Monoxide in Meat and Fish Packaging: Advantages and Limits. Laboratory of Food Quality and Food Safety, 7(1), 12. 
doi: 10.3390 foods 7020012 .

Giovannucci, D., \& Satin, M. (2007). Food Quality Issues: Understanding HACCP and Other Quality Management Techniques. Available at SSRN: https://ssrn.com/abstract=996762.

Jedermann, R., Pötsch, T., \& Lloyd, C. (2014). Communication techniques and challenges for wireless food quality monitoring. Philos Trans A Math Phys Eng Sci., 372, 20130304. doi: 10.1098rsta.2013.0304.

Klymenko, L.P., Pizintsali, L.V., Aleksandrovska, N.I., \& Yevdokymov, V.D. (2011). Metrolohiia, standartyzatsiia ta upravlinnia yakistiu. Mykolaiv: Vyd-vo ChDU im. Petra Mohyly (in Ukrainian).

Leal-Ramos, M., Alarcón-Rojo, A., Gutiérrez-Méndez, N., Mujica-Paz, H., Rodríguez-Almeida, F., \& Quintero-Ramos, A. (2018). Improving Cull Cow Meat Quality Using Vacuum Impregnation. Foods, 7(5), 74. doi: 10.3390 foods 7050074.

Li, K., McKeith, A.G., Shen, C., \& McKeith, R. (2017). A Comparison Study of Quality Attributes of Ground Beef and Veal Patties and Thermal Inactivation of Escherichia coli O157:H7 after Double Pan-Broiling Under Dynamic Conditions. Foods, 7(1), 1. doi: 10.3390 foods 7010001 .

Mack, M., Dittmer, P., Veigt, M, Kus, M, Nehmiz, U., \& Kreyenschmidt, J. (2014). Quality tracing in meat supply chains. Philos Trans A Math Phys Eng Sci.,
372(2017), 20130308. doi: 10.1098/rsta.2013.0308.

Pethick, D.W., Ball, A.J., Banks, R.G. \& Hocquette, J.F. (2010). Current and future issues facing red meat quality in a competitive market and how to manage continuous improvement Animal Production Science, 51(1), 13-18. doi: 10.1071/AN10041.

Popova, N.V., \& Mysiura, T.H. (2012). Kontrol yakosti ta bezpeky produktsii haluzi: Kurs lektsii dlia stud. napriamu 6.051701 "Kharchovi tekhnolohii ta inzheneriia" den. ta zaoch. form navch. K.: NUKhT, 2012. 176 p. (in Ukrainian).

Raab, V., Petersen, B., \& Kreyenschmidt, J. (2011). Temperature monitoring in meat supply chains. Br. Food J., 113, 1267-1289. doi: 10.110800070701111177683.

Rudnytskyi, V.S., Stetsiv, I.I., \& Stetsiv, R.I. (2010). Orhanizatsiia obliku, kontroliu ta analizu: navch.naoch. posib. Lviv. komerts. akad. (in Ukrainian).

Vershyhora, Ye.Yu. (2015). Marketynhova tovarna polityka: Navchalnyi posibnyk dlia studentiv vyshchykh navchalnykh zakladiv. Ternopil: Aston (in Ukrainian).

Zhang, M., Meng, X., Bhandari, B., \& Fang, Z. (2016). Recent Developments in Film and Gas Research in Modified Atmosphere Packaging of Fresh Foods. Crit Rev Food Sci Nutr., 56(13), 2174-2182. doi: 10.1080/10408398.2013.819794. 